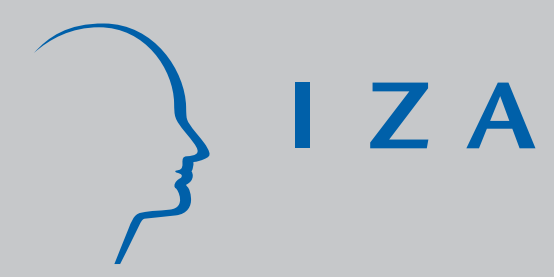

IZA DP No. 1750

\title{
Immigrant Earnings:
}

A Longitudinal Analysis

\section{Barry R. Chiswick}

Yew Liang Lee

Paul W. Miller

September 2005 


\title{
Immigrant Earnings: A Longitudinal Analysis
}

\author{
Barry R. Chiswick \\ University of Illinois at Chicago \\ and IZA Bonn \\ Yew Liang Lee \\ University of Western Australia \\ Paul W. Miller \\ University of Western Australia \\ and IZA Bonn
}

\section{Discussion Paper No. 1750 \\ September 2005}

\author{
IZA \\ P.O. Box 7240 \\ 53072 Bonn \\ Germany \\ Phone: +49-228-3894-0 \\ Fax: +49-228-3894-180 \\ Email: iza@iza.org
}

\begin{abstract}
Any opinions expressed here are those of the author(s) and not those of the institute. Research disseminated by IZA may include views on policy, but the institute itself takes no institutional policy positions.
\end{abstract}

The Institute for the Study of Labor (IZA) in Bonn is a local and virtual international research center and a place of communication between science, politics and business. IZA is an independent nonprofit company supported by Deutsche Post World Net. The center is associated with the University of Bonn and offers a stimulating research environment through its research networks, research support, and visitors and doctoral programs. IZA engages in (i) original and internationally competitive research in all fields of labor economics, (ii) development of policy concepts, and (iii) dissemination of research results and concepts to the interested public.

IZA Discussion Papers often represent preliminary work and are circulated to encourage discussion. Citation of such a paper should account for its provisional character. A revised version may be available directly from the author. 
IZA Discussion Paper No. 1750

September 2005

\section{ABSTRACT}

\section{Immigrant Earnings: A Longitudinal Analysis*}

This paper uses the Longitudinal Survey of Immigrants to Australia to analyze the determinants of the level and growth in earnings of adult male immigrants in their first 3.5 years in Australia. The theoretical framework is based on the immigrant adjustment model, which incorporates both the transferability of immigrant skills and selectively in migration. The cross-sectional and longitudinal analyses generate similar findings. The level and relative growth of earnings are higher for immigrants with higher levels of skill and who are economic/skills tested migrants, as distinct from family based and refugee migrants. The analysis indicates that immigrant economic assimilation does occur and that in these data the cross-section provides a good estimate of the longitudinal progress of immigrants. The findings are robust across statistical techniques.

JEL Classification: F22, J31, J61

Keywords: immigrants, wages, longitudinal survey, inertia model, Australia

Corresponding author:

Barry R. Chiswick

Department of Economics (M/C 144)

University of Illinois at Chicago

601 South Morgan Street (2103 UH)

Chicago, IL 60607-7121

USA

Email: brchis@uic.edu

* Chiswick acknowledges the research support of the Institute of Government and Public Affairs, University of Illinois and Miller acknowledges financial assistance from the Australian Research Council. Helpful comments were received from two anonymous referees. 


\section{INTRODUCTION}

Much of the recent immigration literature has sought to understand immigrants' economic adjustment, as measured by their earnings. The economic framework for this type of analysis was set out in Chiswick (1978) (1979). The early studies, based primarily on cross-sectional data, established an important empirical regularity: immigrant earnings improved rapidly at first and then at a slower rate with duration of residence in the host country.

There has been some questioning of this type of result. Using data from the 1970 U.S. Census, Chiswick (1980) was the first to raise the question as to whether the cross-sectional estimates were biased estimates of the longitudinal adjustment process, and concluded there was no obvious significant bias. The cross-section may provide biased estimates of the longitudinal effects if there is selectivity in the return migration of immigrants, or if there are changes over time in the unmeasured dimensions of the quality of immigrants. In particular, the cross-section provides upward biased estimates if the least successful of immigrants have a greater propensity to remigrate or if more recent immigrant cohorts have lower unmeasured dimensions of ability relevant for the labor market. Borjas (1985) has argued that a decline over time in unmeasured dimensions of immigrant quality is responsible for the observed positive effect of duration on immigrant earnings in cross-sectional data, and that there is no assimilation effect. This interpretation has been disputed by Chiswick (1986) and Duleep and Regets (1996, 1997), among others.

The problem facing applied researchers is that determining whether immigrants experience growth in earnings requires longitudinal data, and there are few longitudinal data sets available that contain a sufficient number of observations on immigrants for statistical analysis. ${ }^{1}$ The Longitudinal Survey of Immigrants to 
Australia, Panel I (LSIA) is one exception to this general situation. This is a survey of 5,192 immigrants who arrived in Australia in the period 1993-1995. These immigrants were followed for their first $3 \frac{1}{2}$ years in Australia. While this is a short panel, the quality of the data and the lack of alternative data sets make it an extremely valuable resource for the analysis of the immigrant adjustment phenomenon. Moreover, it would be expected that the labor market adjustment of immigrants would be most pronounced in their first few years in the destination.

The structure of this paper is as follows. Section II provides details on the Longitudinal Survey of Immigrants to Australia, including a review of the earnings data. Section III outlines the hypotheses and the statistical framework. Section IV presents the empirical findings, while Section V contains a summary and conclusion.

\section{THE LONGITUDINAL SURVEY OF IMMIGRANTS TO AUSTRALIA}

This paper is based on the Longitudinal Survey of Immigrants to Australia, Panel I (LSIA), a longitudinal study of recently arrived immigrants who received their visas before entry into Australia. The population represented in the sample is all Principal Applicants (PAs), aged 15 years and over, who arrived in Australia with their visas in the two-year period of September 1993 to August $1995 .^{2}$ Principal Applicant immigrants selected for interview were those who settled in State and Territory capital cities (including major urban centers close to capital cities such as Newcastle and Wollongong), as well as Cairns. Reflecting the geographic concentration of immigrants in Australia, only 4 to 5 percent of the total of Principal Applicant immigrants is excluded from the coverage of the survey because they live outside of these areas. 
The final LSIA sample was 5,192 Principal Applicant arrivals. This represents about seven percent of the total Principal Applicants that arrived in the two-year survey period. The population from which the sample was selected at random was stratified according to visa eligibility category and also by about fifty regions or countries of birth. ${ }^{3}$ Principal applicants in smaller states and territories were oversampled. Sample weights are applied in all the econometric analyses.

The information collected by way of personal interview includes demographic characteristics, socioeconomic status, family background and location details. Data on the Principal Applicant’s demographic characteristics include information on gender, age, marital status, country of birth, and ethnicity. The major socioeconomic status variables include education level, employment status (before and after migration), and earnings after migration from all sources. The type of visa that permitted entry was also recorded.

Immigrants were to be interviewed three times. The first interview was to take place approximately five or six months after arrival, the second interview one year later, and the third interview a further two years later. The first, second and third waves of interviews commenced in March 1994, March 1995 and March 1997, respectively. Each wave of interviews was spread over a period of two years. While this means that immigrants were followed for only their first $3 \frac{1}{2}$ years in Australia, the limited longitudinal information on immigrants available in the major immigrant receiving countries makes this an extremely valuable data set for the study of the economic progress of immigrants.

The analyses are restricted to 15-64 year old male immigrants who were working in a job, a business or a farm at the time of the interview. The measure of earnings used is the average weekly earnings from all wage and salary jobs. Very few 
of the immigrants were self-employed. Preliminary examination of these data across the three waves of interviews did not uncover any systematic patterns consistent with attrition bias having a major impact on the analysis (see Appendix, available upon request). As each set of interviews was spread over several years, all earnings data have been deflated to real (1990) values using a consumer price index.

Previous research has drawn attention to the important role of post-arrival labor market experience, and special attention has been given in this study to the construction of an Australian job experience variable (ALME). In wave one of the LSIA, information was collected on jobs held at the time of the interview, and, where relevant, the job prior to this with the longest duration. In subsequent waves, information was obtained on the status of any (main) job held at the time of the previous interview, on any current job and, where relevant, on the job prior to this with the longest duration. Figure I describes some possible job histories. Each rectangle represents a job, with the length varying according to job duration. Rectangles that are shaded are ones for which information is available on the duration of the job. Rectangles that are not shaded represent jobs where there is no information on the duration. The Australian job experience variable is given by the sum of the shaded rectangles. The measurement error for this variable is given by the sum of the unshaded rectangles.

\section{[INSERT FIGURE 1HERE]}

For individuals with intermittent employment, the Australian job experience variable will understate the true level of experience, while for those with continuous employment, any mismeasurement will be minimal. This mismeasurement is likely to 
be small in the main sets of analyses in the second part of Section IV, where the sample is restricted to immigrants who held a job at the time of each of the three waves of interviews.

\section{HYPOTHESES AND STATISTICAL FRAMEWORK}

This section develops a number of hypotheses as to the economic progress of immigrants. The two key determinants of economic progress are the transferability to the country of destination of skills acquired in the country of origin, and selection of immigrants on the basis of innate ability and motivation for economic advancement. Skills are defined broadly to include labor market information, destination language proficiency, occupational licenses, certification or credentials, as well as more narrowly defined task-specific skills. The international transferability of skills depends on differences in the language, culture, technology, economic and legal structures between the countries of origin and destination, as well as the motive for migrating. The selection depends on both the self-selection of those seeking an immigrant visa (demand for visas) and the criteria used for issuing a visa by the immigration authorities (supply of visas).

There are two broad sets of skills that have been the focus of research into the economic progress of immigrants, schooling and labor market experience or on-thejob training. The effects of schooling and labor market experience on earnings are expected to be greatest for those whose skills are most transferable to the destination country’s labor market.

The transferability of skills acquired through formal and informal training in the country of origin is least for refugees, as the skills this group would have acquired in their country of origin would have less applicability in Australia than those of 
economic immigrants (Chiswick 1979). This is because the migration of refugees is less motivated by likely economic success in the destination. In comparison, economic migrants from countries with a language, culture, level of economic development and economy similar to the country of destination should experience few skill transferability problems.

The weaker the transferability of skills, the lower the earnings and the greater the probability of unemployment for the immigrant when he/she arrives in the destination. After migration, however, immigrants make implicit and explicit investments that complement the skills they have. These investments increase the transferability of previously acquired skills and create new skills. Labor market experience in the country of destination has the largest impact on earnings for those whose skills acquired in the country of origin were the least transferable.

It is also hypothesized (see Chiswick 1979, 1999) that immigrants tend to have a higher level of innate ability and work motivation than their fellow countrymen with similar characteristics who remain at home. As there are costs of migration (including costs of moving and costs of subsequent adjustment in the new environment), the selfselection of migrants in favor of the more able would be more pronounced the larger the out-of-pocket or direct costs of migration. An implication is that the favorable self-selection will be less intense for economic migrants from English-speaking countries since it involves smaller costs of migration. Compared with economic migrants, refugees are less likely to be self-selected on the basis of high labor market ability and work motivation, as factors other than labor market success are important determinants of their migration decision.

The analysis uses the human capital earnings function. The basic estimating equation used in this research is a linear regression of the natural logarithm of average 
weekly earnings (from all wages and salary jobs before any deduction, such as tax or superannuation) on the exogenous variables:

(1) Educational Attainment - measured as years of education,

(2) Potential pre-immigration labor market experience - measured as Age at Arrival-Education-5, measured in years,

(3) Australian labor market experience, measured in months, constructed from the sets of information on interview dates and the dates of commencement and termination of jobs,

(4) ESDC - a dichotomous variable equal to unity if born in an Englishspeaking developed country (US, UK, Canada and Ireland),

(5) Visa Category - dichotomous variables equal to unity if Refugee (Humanitarian Category), Preferential Family Category, Concessional Family, or Business Skills/Employer Nominated Scheme, with Independent immigrants as the benchmark,

(6) Marital Status, a dichotomous variable equal to zero for those who are married,

(7) English Language Proficiency, a dichotomous variable set equal to zero for those who speak only English, speak English best or speak English very well, otherwise it is zero,

(8) Whether post-school qualifications were obtained in Australia,

(9) Hours worked - Natural logarithm of usual hours of work per week in wage and salary employment.

\section{EMPIRICAL FINDINGS}

\section{(a) Repeated Cross-Sectional Analysis}


Table 1 reports the results of the multiple regression (OLS) analysis with logarithmic weekly earnings being the dependent variable for each of the three waves. In wave one (column (i)), the positive and significant coefficients on the variables for education, pre-immigration experience, post-immigration work experience and English-speaking developed countries indicate that greater pre-immigration human capital, a greater transferability of skills, and post-arrival accumulation of human capital on-the-job result in higher weekly earnings. The return to pre-immigration education, at 4.3 percent per year of schooling, among this sample of recent arrivals in the 1990s, is several percentage points lower than the 6.1 percent reported in the analysis of all immigrants in the 1981 Australian Census (Chiswick and Miller 1985). It is also much lower than the 8.2 percent return to education among the Australian born, and this differential in returns to schooling is generally argued to reflect the lessthan-perfect international transferability of the skills learned in school (Chiswick and Miller 1985). Nevertheless, a partial effect as high as 4.3 percent indicates that a high proportion of the immigrants' human capital acquired through school was transferable to the Australian labor market. It is also seen that the small group with educational qualifications obtained in Australia have a substantial earnings advantage (coefficient of 0.119 ) over other groups.

\section{[INSERT TABLE 1 HERE ]}

Additional years of overseas work experience increase weekly earnings in Australia by about one-half of one percent, evaluated at ten years of experience. ${ }^{4}$ In a study of immigrant earnings based on the 1981 Australian Census, Chiswick and Miller (1985) found that the earnings returns to pre-immigration experience were around 0.76 percent, evaluated at 10 years of experience. In comparison, the earnings returns to a year of experience among the Australian-born were about 1.7 percent 
(evaluated at 10 years of experience). Hence, skills acquired abroad on-the-job appear to be of minimal value in the Australian labor market.

It is sometimes suggested that the formal education system is associated with the production of general skills while labor market experience is associated with more job-specific skills. If these associations are broadly correct, then the results listed in Table 1 suggest that there is a higher degree of international transferability of general skills than of more job and occupation specific skills. This is an intuitively appealing result.

The Australian labor market experience variable, which is measured in months, reveals that this is of far greater importance than pre-immigration labor market experience. The coefficient of 0.035 in Table 1 for wave one indicates that earnings rise by 3.5 percent with each month of labor market activity in Australia. Note that the mean of this variable is only 3.3 months.

Miller and Volker (1987), however, have reported an earnings increment of 7 percent over the first year of labor market experience for Australian youth. From this perspective, the 3.5 percent higher earnings for each extra month of Australian work experience is at the high end of expectations. The higher earnings growth with Australian labor market experience recorded in this immigrant analysis may derive from large investments and the return on these investments made in the first few months or complementarities between Australian work experience and preimmigration work experience. ${ }^{5}$

Compared with Independent migrants, Refugees (Humanitarian visas) and the partially tied movers (Preferential Family and Concessional Family categories) had lower weekly earnings, though for the small group of refugees participating in the labor market so soon after arrival in Australia the earnings effect is not statistically 
significant. Only those in the Business Skills/Employer Nominated Scheme had higher weekly earnings than Independent migrants. This category is dominated by individuals who entered Australia under an Employer Nominated Scheme, and the higher earnings they receive appear to be a further benefit of the required pre-arranged employment under this program.

There are three other variables in the model, marital status, English language proficiency and the log of hours worked per week in the survey week. Each of these is statistically significant. Immigrants who are married earn around 8 percent more than their non-married counterparts. The magnitude of this marriage premium is similar to that recorded in analyses for the broader Australian labor market (see Chiswick and Miller 1985).

Immigrants who are proficient in English have 19 percent higher earnings than those with limited English language skills. This premium to English skills is far higher than has previously been reported for Australia, but is of the same order of magnitude as that documented for the U.S. labor market (see Chiswick and Miller 1995).

Finally, it is noted that the elasticity of weekly earnings with respect to hours worked is 1.059 , and this is not significantly different from unity. Thus, hourly earnings do not appear to vary with the number of hours worked per week, other things being the same, at about 6 months in the country.

The results in Table 1 for wave two (as reported in column (ii)) and wave three (column (iii)) broadly resemble those in wave one. However, the consistent patterns of change for the pre-immigration experience, Business Skills/Employer Nominated Scheme and Refugee variables are noted. Unlike in wave one, the effects on weekly earnings of pre-immigration labor market experience and being in the Business 
Skills/Employer Nominated Scheme categories are not statistically significant. The findings for the pre-immigration experience variable can be viewed as implying that pre-immigration experience is used as a type of screening device. Pre-immigration experience attracts some rewards initially, but the information it conveys is rapidly displaced by information that Australian employers learn on the job. Consequently, after immigrants have been in Australia for even a limited time the value of preimmigration experience as a signaling device is diminished to statistical and economic insignificance.

The statistical insignificance of the Business Skills/Employer Nominated Scheme variable in Waves 2 and 3 suggests the advantages associated with prearranged employment are short-lived. In comparison, the emergence to statistical significance of the negative effect on earnings of the refugee variable suggests the wave one finding is atypical, and may be associated with their low propensity for being employed within the first six months and with the small proportion who are employed, as well as the characteristics of employment arranged by sponsors for the refugees. A more reliable assessment of the relative earnings of refugees might only be gained after a few years in the labor market as more of them become employed and as others move away from jobs found by sponsors to being more self-reliant.

Finally, the change in size of the estimated elasticity of weekly earnings with respect to hours worked is noted. This elasticity declines from 1.06 in wave one to between .53 (wave 2) and .79 (wave 3), both estimates being significantly less than unity. Estimates of this elasticity of earnings with respect to hours worked below unity are conventional in the literature.

The basic patterns in these results can be summarized succinctly: 
1. With time in Australia, there is an erosion of the initial value placed on overseas experience in the Australian labor market.

2. Australian labor market experience is an important determinant of weekly earnings.

3. The relative earnings position of the independent-category immigrants improves with duration of residence in Australia.

The pattern of change in the relative earnings position of immigrants according to visa category is illustrated in Figure 2. This shows clearly the favorable performance of the independent-category immigrants.

\section{[INSERT FIGURE 2 HERE]}

One of the potential shortcomings of the analyses reported in Table 1 flows from the low incidence of paid work among immigrants in the first few years in Australia, and the fact that the difficulties in obtaining work are not uniform across groups of immigrants. For example, only 41 percent of immigrants with valid data in the survey were in paid employment in wave one. In wave two this figure was 47 percent, and in wave three it had increased to 69 percent. Three percent of the wage and salary earners in the analysis for wave one were Refugees. By wave three, however, this had increased to nine percent as it takes longer for refugees to find jobs. As the sample of individuals in paid employment that emerges is potentially nonrandom, the Table 1 results may be characterized by sample selection bias.

This potential problem may be accommodated using the two-step procedure developed by Heckman (1979). Hence, for each of the waves, a model of the probability of being in paid employment is estimated, and the estimates of this are 
used to construct a sample selection correction term, $\lambda$, for inclusion in the earnings equation. Inclusion of this $\lambda$ variable ensures, in principle, that the error term is zeromean, and hence that estimation of the earnings equation using OLS will provide consistent estimates.

The selection model of the probability of being in paid employment was specified to include, where possible, the variables in the earnings equation, and also variables for the individual's family circumstances which do not directly enter the earnings equation. ${ }^{6}$ These variables, which will reflect pressures and motivations to obtain paid employment, are for the presence of a spouse in the household who migrated with the Principal Applicant, the presence of a different (i.e., non-migrating unit) spouse, whether the male has children, and whether they reside with migrating unit relatives or with other relatives. Most of these variables were statistically significant, and the significance of these identifying restrictions provides a sound basis for the use of the model in selectivity corrections.

Before examining the selectivity corrected results in detail, it is useful to focus on the findings for the sample selection correction terms. These are listed in Table 2. It is apparent from this information that as the fraction of the sample that is in paid employment has increased in successive simple waves, the importance of sample selection bias has diminished. Hence, the coefficient on the lambda term falls from -0.501 in wave one to -0.392 in wave three, the ' $t$ ' value changes from 3.37 to 1.40 , and the product of the coefficient on lambda and the mean of lambda, $\hat{c} \bar{\lambda}$, which provides a measure of the impact of sample selection bias on the observed earnings distribution, changes from -0.376 to -0.172 .

[INSERT TABLE 2 HERE ] 
In each wave of data the coefficient on the sample selection term is negative. This indicates that there is a negative correlation between the error terms in the selection equation determining whether the immigrant is in paid employment and the earnings equation. That is, immigrants with an above average probability of being in paid employment, given their observed characteristics, have a lower than average expected earnings, again given their observed characteristics. In other words, there is negative selection into paid employment. This suggests that the immigrants most likely to work during the first few years in Australia are driven by factors other than comparative advantage. Necessity is an obvious candidate. Arrangements made by sponsors who supplant self motivation/initiative are another possibility. There is no comparison literature which permits the reasonableness of this conjecture to be assessed. The internal consistency and intuitive appeal of a diminishing role for negative labor market selectivity with duration of residence in Australia is the only yardstick that appears to be available.

The selectivity corrected earnings analysis results, as presented in Table 3, have three main features. First, the estimated effects of education and pre-immigration experience are larger in those selectivity corrected equations where selection is important (waves one and two). However, the pattern of change across the three sets of analyses on the estimated effect of pre-immigration experience is the same under the alternative (OLS) method of estimation. The persistence of the decline in the value of overseas experience with time in Australia across methods of estimation suggests that attention can be focused on understanding the reasons for this change with a longer duration in Australia. 
[INSERT TABLE 3 HERE ]

Second, the coefficient on the variable for immigrants from English-speaking countries is much smaller in magnitude in the selectivity corrected equations (again, where selection is important, in waves one and two), and is in fact statistically insignificant in the wave one analysis. The change in statistical significance in this instance is due to the diminution of the estimated impact more than an increase in its standard error. Similarly, the estimated effect of the English proficiency variable is much smaller, and statistically insignificant, where self-selection has been found to be important.

Third, the estimated coefficients on the Preferential and Concessional Family visa category variables are smaller (in absolute value) compared to the uncorrected estimates. In other words, there are unobservables that lower earnings which are correlated with the family visa categories that are controlled for through the sample selection correction. The refugee variable is highly significant (and negative) in the selection equation, and the selection corrected estimates reveal that the small group of refugees who work in waves 1 and 2 are associated with higher earnings. The analyses reported below, with the sample restricted to those with earnings in all three waves of the survey, suggest that the results in Tables 1 and 3 are capturing the effects of refugees with more intermittent labor market involvement. Finally, the apparent anomaly associated with the Business Skills/Employer Nominated Scheme variable is removed by the correction for selectivity bias.

The effects of the variables on earnings after correction for sample selectivity bias can be considered using the derivative 


$$
\frac{\delta \ln Y}{\delta X_{k}}=\hat{\beta}_{k}+\hat{c} \frac{\partial \lambda}{\partial X_{k}}
$$

where $\hat{\beta}_{k}$ is the estimated coefficient on the $k^{\text {th }}$ variable in the earnings equation, $\hat{c}$ is the estimated sample selection effect, ad $\lambda$ is the sample selection correction factor (Dolton and Makepeace 1987, Greene 1991). Thus, the effect of a variable such as visa category on earnings comprises the direct effect given by the estimated coefficients from Table $3\left(\hat{\beta}_{k}\right)$, and an indirect effect from the probit selection equation ( $\hat{c} \frac{\partial \lambda}{\partial X_{k}}$ ). This indirect effect accounts for the difference between the results presented in Tables 1 and 3. Comparison of Tables 1 and 3 shows that this indirect effect that occurs via the selection equation for the visa variables are important. These results show that family-based immigrants are outperformed by Independent immigrants. Once account is taken of selection bias in labor market employment among the foreign born, refugees have a comparatively good (compared to familybased immigrants) performance in the Australian labor market.

\section{(b) Longitudinal Analysis}

The results reported above are based on analysis of the LSIA data treated as a repeated cross-section. In this section the longitudinal dimension of the survey is used to explore further the origin of the earnings growth of immigrants over their first three and a half years of labor market activity in Australia.

There are a number of models that might be used in this type of analysis, including first difference and random effects models. However, the model that seems to be best suited to address questions related to immigrant earnings growth is Nakamura and Nakamura's (1985) inertia model. With this model, which is a variant 
of the first difference model, earnings at the time of the wave three interview are related to earnings at the time of the wave one interview, the hours worked at the time of the wave one interview, and the immigrant's personal characteristics and hours worked at the time of the wave three interview. That is, in summary form:

$$
\ln Y_{3, i}=\beta_{0}+\beta_{1} \ln Y_{1, i}+\beta_{2} \ln H_{1, i}+\beta_{3} X_{3, i}+\beta_{4} \ln H_{3, i}+\varepsilon_{i}
$$

where $\ln Y_{t, i}$ refers to the natural logarithm of the weekly earnings of individual $\mathrm{i}$ in period $t, \ln H_{t, i}$ is the natural logarithm of hours worked in period t, $X_{i}$ is a vector of immigrant i’s personal characteristics (e.g., educational attainment, visa category), and $\varepsilon_{i}$ is a random disturbance term. As argued by Nakamura and Nakamura (1985), any person-specific fixed effects relevant to earnings should be embedded in the lagged earnings and hours terms, and hence captured by the parameters $\beta_{1}$ and $\beta_{2}$. These fixed effects have the same impact on earnings year after year. ${ }^{7}$

The coefficients on the observed explanatory variables $\left(X_{i}\right)$ will usually differ from those obtained from restricted models of the type estimated separately for waves one and two, namely:

$$
\ln Y_{3, i}=\alpha_{0}+\alpha_{2} X_{3, i}+\alpha_{3} \ln H_{3, i}+v_{i}
$$

Specifically, $\beta_{3}$ will capture the impact of the observed variable after controlling for the earnings received in the previous period. Another way of looking at this is that, given the control for the fixed effects via the lagged earnings term, $\beta_{3}$ will record, in a proxy sense, the impact of changes from year to year in the characteristics and circumstances of individuals that lead to changes in earnings (Nakamura and Nakamura 1985, p.20).

The total effect of a variable $X_{k}$ on current period earnings in the inertia model is given as: 


$$
\frac{\partial \ln Y_{3}}{\partial X_{k}}=\beta_{k}+\beta_{1} \frac{\partial \ln Y_{1}}{\partial X_{k}}+\beta_{2} \frac{\partial \ln H_{1}}{\partial X_{k}}
$$

That is, any given observed variable will have two channels of influence on current earnings. The first of these arises from the observed variable being a proxy for changes in the personal circumstances that lead to changes in earnings over time $\left(\beta_{k}\right)$. The second arises because the observed variable is associated with fixed personspecific effects that are embedded in the lagged earnings and hours of work terms. This part of the influence is given by $\beta_{1} \frac{\partial \ln Y_{1}}{\partial X_{k}}+\beta_{2} \frac{\partial \ln H_{1}}{\partial X_{k}}$.

Nakamura and Nakamura (1985, p.19) note that the model can be expanded to include changes in variables that can be directly measured and which are thought likely to have a major impact on earnings. An examination of the LSIA data suggests that the main such variable is actual labor market experience. Accordingly, the equation to be estimated in this study is:

$$
\ln Y_{3, i}=\beta_{0}+\beta_{1} \ln Y_{1, i}+\beta_{2} \ln H_{1, i}+\beta_{3} X_{3, i}+\beta_{4} \ln H_{3, i}+\beta_{5} \Delta A L M E_{3-1, i}+\varepsilon_{i}
$$

where $\triangle A L M E_{3-1, i}$ is the amount of labor market experience accumulated between waves one and three by immigrant $\mathrm{i}$.

Table 4 (column (iii)) presents estimates of Nakamura and Nakamura’s (1985) inertia model for wave three. This table also lists results of the standard model for the subset of individuals who were in the wage and salary sample in both waves one and three (columns (i) and (ii) respectively). Finally, the table contains a variant of the Nakamura and Nakamura (1985) model where the change in earnings between waves one and three is related to the set of explanatory variables contained in equation (1) (see column (iv)). While this specification is obviously related in a mathematical 
sense to the column (iii) equation, the presentation of this alternative enables direct comment on the argument of Duleep and Regets (1996)(1997) that immigrants with the lowest earnings upon arrival experience the most rapid subsequent earnings growth.

[INSERT TABLE 4 HERE ]

The first feature of Table 4 is that the lagged earnings term in the inertia model is highly significant. The coefficient is in elasticity form: one percent higher earnings in wave one is associated with a 0.57 percent higher earnings in wave three. In the context of this model this implies that the person-specific fixed effects that are embedded in the lagged earnings term are very important to the study of contemporary (wave three) earnings. Nakamura and Nakamura (1985) estimate their inertia models in log-linear form, and so the coefficients in the two studies are not directly comparable. However, calculation of elasticities for prime-age males from Nakamura and Nakamura's (1985) study reveals these to be broadly similar to that reported in Table 4.

While the person-specific fixed effects are important, there is also considerable variability in earnings. This is not unexpected: previous studies of the Australian labor market for women (see Le and Miller 2001) and youth (Miller 1989) and for the US labor market (see Lillard and Willis 1978) show there is considerable movement from one year to the next in the position held in the earnings distribution. This variability may be because some of the immigrants’ circumstances change. Or it could be because of luck, chance events, or reflect measurement errors.

This variation is captured in the inertia model in three ways. First, it is captured through the inclusion of the "Australian actual labor market experience" 
variable. This variable is measured in months. It shows that earnings increase by one percent per month of Australian labor market experience. The mean length of time between the wave one and wave three interviews was three years and one month (range from 34 to 52 months), and the mean of the actual labor market experience variable is slightly under three years (range from 9 to 51 months). Hence, this recorded change between waves one and three accounts for around 35 percentage points earnings growth. This is a fairly impressive statistic, but it is well known that growth in earnings is quite rapid among recent new entrants and re-entrants to the labor market.

The second way in which the variation in earnings between waves one and three is accounted for in the inertia model is through personal and institutional characteristics such as education attainment, birthplace and visa category. Each of the significant explanatory variables in the wave three cross-sectional analyses is significant in the inertia model, albeit with a coefficient much smaller in absolute value. For example, the coefficient on the education variable is 0.035 in the inertia model and 0.059 in the comparison pure cross-sectional analysis undertaken for wave three. This suggests that in the cross-sectional analysis, about forty percent of the impact of education is due to person-specific effects that have the same impact yearto-year. The other sixty percent arises because education is a proxy for changes in the individual's personal circumstances that affect earnings. This would capture the influence of the common saying that better educated people create their own "luck."

The third set of factors (other than person-specific fixed factors) that give recognition to the variation in immigrants' earnings is the residual term. This accounts for about 40 percent of the total variation in immigrant earnings at the time of the wave three interviews. 
In Table 4, column (iv) the change in earnings between waves 1 and 3 is related to the same set of explanatory variables used in column (iii). This model is linked mathematically to that in column (iii) through the subtraction of the log of wave one earnings from both sides of the model. Hence, the coefficient on the lagged log earnings variable is -0.436 . This shows that earnings growth is slower for those with higher initial post-arrival wages, a strong empirical regularity that is consistent with the arguments of Duleep and Regets (1996) (1997).

Given the links between contemporary and lagged wages, it is likely that $E\left(\ln Y_{1, i} \varepsilon_{i}\right) \neq 0$ in equation (5), leading to inconsistent estimates. This potential problem is addressed in this analysis by instrumenting the actual lagged wage variable by a predicted lagged wage variable. The predictions are obtained from the model in column (i) of Table $4 .^{8}$ Results are presented in Table 5. Other variables the same, the elasticity of wave 3 earnings with respect to predicted wave 1 earnings is 0.8 , that is, a 10 percent higher predicted wave 1 earnings is associated with an 8 percent higher wave 3 earnings. In the inertia model to explain the change in observed earnings, a 10 percent increase in predicted wave 1 earnings reduces the increment in earnings by 10 percentage points. These patterns suggest that the estimated impacts on the lagged wage variable in the Table 4 results are attenuated towards zero. However, they also show that the major findings from the Table 4 analyses carry across to the instrumental variable framework.

[INSERT TABLE 5 HERE ]

Thus, the analysis demonstrates that even after controlling for earnings in wave 1, the skills of immigrants influence subsequent earnings. Those who have had 
more human capital (whether measured by years of schooling, educational qualifications obtained in Australia, English language proficiency or months of Australian labor market activity) experience greater wage growth. Those with more highly transferable skills (come from an English-speaking developed country or are Independent or Business Skills/Employer Nominated Scheme immigrants) also experience a steeper increase in earnings.

\section{CONCLUSION}

This paper addresses the debate in the literature regarding the economic progress of immigrants. In particular, it is concerned with the labor market adjustment of immigrants in a longitudinal survey, as distinct from most of the literature which uses simple cross-sections, repeated cross-sections, or synthetic cohorts. The data are from the Longitudinal Survey of Immigrants to Australia (LSIA).

The LSIA follows for a period of 3 years a cohort of principal applicants age 15 and over who arrived in Australia with a visa in 1993 to 1995 . Wave 1 was conducted at about 6 months in Australia and Wave 3 at about 31/2 years duration. Several hypotheses are developed based on models of the international transferability of human capital and the degree of favorable selectivity based on immigrant motive for migration and type of immigrant visa.

The statistical analysis for adult males progresses from Ordinary Least Squares (OLS) within survey waves, to Heckman's (1979) selectivity correction analysis within waves, to explicit use of the longitudinal features of the data using Nakamura and Nakamura's (1985) inertia model, to the use of this model with an 
instrumental variables estimation of lagged earnings. Although there are some differences, the empirical findings tend to be robust across statistical techniques.

There is considerable immigrant adjustment. For the group of immigrants in the LSIA reporting positive wage and salary earnings at the first and final interviews, which were conducted about three years apart, real weekly earnings grew by more than 25 percent. Nakamura and Nakamura’s (1985) inertia model is used to account for the earnings of immigrants at the final interview. In the inertia model, contemporary earnings are related to lagged earnings as a means of capturing the person-specific fixed effects embedded in the earnings data. It is shown that in these data the elasticity of the current earnings with respect to lagged earnings is as high as 0.7. This shows that the person-specific fixed effects are important. Moreover, it is also shown that the changes in earnings between the first and final interviews are negatively related to the initial earnings. That is, those immigrants who start out in low-paying jobs experience more rapid growth in earnings, ceteris paribus, perhaps because of their investment in destination-specific human capital. A larger investment in job-related training implies lower reported earnings during the investment period, and higher earnings when the benefits from the investment are received. The result is a steeper observed earnings profile and a negative correlation between initial earnings and earnings growth.

Empirically, the level of earnings in wave 1, wave 2, and wave 3, and the growth in earnings from wave 1 to wave 3 , is greater the higher the level of human capital, that is, the greater the educational attainment, educational qualifications acquired in Australia, Australian work experience and English language proficiency. Coming from an English-speaking developed country and on a skill-based visa (Independent migrant or Business Skills/Employer Nominated Scheme visa) also 
results in higher earnings in each wave and a larger increase from wave 1 to wave 3. Pre-immigration labor market experience, on the other hand, diminishes in importance with duration in Australia.

These findings are consistent with the hypothesis that immigrants do experience earnings assimilation in the destination labor market and that the adjustment in longitudinal data (changes over time for the same person) parallel those found in cross-sectional data (changes across individuals at a point in time). This study is also consistent with the findings of a longitudinal analysis of immigrant occupational adjustment to the Australian labor market (Chiswick and Miller 2005). It provides support for both the usefulness of cross-sectional data for the analysis of immigrant adjustment, as well as the value of longitudinal surveys of immigrants. 
TABLE 1: Regression Estimates of Logarithmic Weekly Earnings for Male Immigrants 15-64 Years of Age With a Job, Longitudinal Survey of Immigrants to Australia

\begin{tabular}{|c|c|c|c|}
\hline & (i) & (ii) & (iii) \\
\hline Variable & Wave One & Wave Two & Wave Three \\
\hline \multirow[t]{2}{*}{ Constant } & 1.349 & 2.678 & 2.269 \\
\hline & $(4.62)$ & $(7.58)$ & (5.69) \\
\hline \multirow[t]{2}{*}{ Education (years) } & 0.043 & 0.062 & 0.048 \\
\hline & (7.14) & $(8.34)$ & (8.65) \\
\hline Post-school quals & 0.119 & -0.023 & 0.109 \\
\hline obtained & $(2.51)$ & $(0.37)$ & (1.93) \\
\hline \multicolumn{4}{|l|}{ Australia } \\
\hline Pre-Immigration & 0.004 & 0.001 & -0.000 \\
\hline Experience (years) & (1.95) & $(0.35)$ & $(0.15)$ \\
\hline Aust. Labor Market & 0.035 & 0.028 & 0.010 \\
\hline Experience & (4.03) & $(4.02)$ & (3.81) \\
\hline \multicolumn{4}{|l|}{ (months) } \\
\hline English-speaking & 0.189 & 0.296 & 0.291 \\
\hline developed countries & $(4.82)$ & (7.28) & (6.56) \\
\hline
\end{tabular}




\begin{tabular}{|c|c|c|c|}
\hline Married & $\begin{array}{l}0.078 \\
(2.43)\end{array}$ & $\begin{array}{l}0.114 \\
(2.53)\end{array}$ & $\begin{array}{l}0.053 \\
(1.61)\end{array}$ \\
\hline Proficient & 0.194 & 0.199 & 0.235 \\
\hline English & $(4.80)$ & (3.69) & $(4.77)$ \\
\hline \multicolumn{4}{|c|}{ VisaCategory (Independent) } \\
\hline Refugee & -0.050 & -0.157 & -0.209 \\
\hline (Humanitarian) & $(0.83)$ & $(2.28)$ & (3.93) \\
\hline Preferential & -0.128 & -0.208 & -0.270 \\
\hline Family & $(4.23)$ & $(5.76)$ & $(8.65)$ \\
\hline Concessional & -0.089 & -0.196 & -0.230 \\
\hline Family & $(2.25)$ & $(4.67)$ & $(5.75)$ \\
\hline Business & 0.113 & 0.039 & -0.049 \\
\hline Skills/ENS ${ }^{(a)}$ & $(1.85)$ & $(0.61)$ & $(0.66)$ \\
\hline Log Hours Worked & 1.059 & 0.533 & 0.791 \\
\hline per Week & $(14.48)$ & $(6.42)$ & $(7.44)$ \\
\hline $\bar{R}^{2}$ & 0.502 & 0.357 & 0.456 \\
\hline Sample size ${ }^{(b)}$ & 1125 & 924 & 1005 \\
\hline
\end{tabular}


Earnings

Notes: 't' statistics in parentheses.

${ }^{(a)}$ ENS denotes Employer Nomination Scheme.

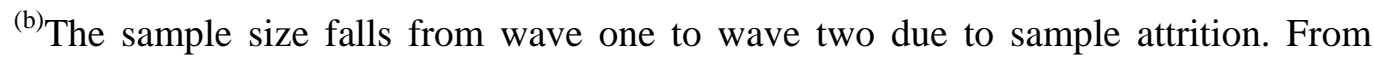
waves two to three the sample attrition is more than offset by the increase in employment, resulting in an overall increase in sample size.

Source: Longitudinal Survey of Immigrants to Australia (Waves One, Two and Three) 
TABLE 2: Sample Selection Correction Terms, Analyses for Male Immigrants 15-64 Years of Age With a Job, Longitudinal Survey of Immigrants to Australia

\begin{tabular}{|c|c|c|c|}
\hline & Wave 1 & Wave 2 & Wave 3 \\
\hline $\begin{array}{l}\text { Estimated } \\
\text { coefficient of }\end{array}$ & -0.501 & -0.557 & -0.392 \\
\hline 't' & 3.37 & 3.97 & 1.40 \\
\hline $\bar{\lambda}$ & 0.750 & 0.648 & 0.438 \\
\hline$\hat{c} . \lambda$ & -0.376 & -0.361 & -0.172 \\
\hline$\%$ of sample & 41 & 47 & 69 \\
\hline working & & & \\
\hline
\end{tabular}

Source: Longitudinal Survey of Immigrants to Australia (Waves One, Two and Three) 
TABLE 3: Selectivity Corrected Estimates of Logarithmic Weekly Earnings for Male Immigrants 15-64 Years of Age With a Job, Longitudinal Survey of Immigrants to Australia

\begin{tabular}{|c|c|c|c|}
\hline & (i) & (ii) & (iii) \\
\hline Variable & Wave One & Wave Two & Wave Three \\
\hline Constant & $\begin{array}{l}1.584 \\
(7.36)\end{array}$ & $\begin{array}{c}3.054 \\
(10.18)\end{array}$ & $\begin{array}{l}2.420 \\
(9.66)\end{array}$ \\
\hline Education (years) & $\begin{array}{l}0.060 \\
(7.41)\end{array}$ & $\begin{array}{l}0.072 \\
(9.06)\end{array}$ & $\begin{array}{l}0.048 \\
(7.96)\end{array}$ \\
\hline Post-school quals & 0.107 & 0.023 & 0.092 \\
\hline obtained & $(1.55)$ & $(0.27)$ & $(1.23)$ \\
\hline Australia & & & \\
\hline Pre-Immigration & 0.013 & 0.010 & 0.004 \\
\hline Experience (years) & (3.78) & (2.94) & (1.09) \\
\hline Aust. Labor Market & 0.033 & 0.026 & 0.010 \\
\hline $\begin{array}{l}\text { Experience } \\
\text { (months) }\end{array}$ & (3.83) & (3.71) & $(4.41)$ \\
\hline English-speaking & 0.076 & 0.148 & 0.310 \\
\hline developed countries & $(1.32)$ & $(2.19)$ & $(5.96)$ \\
\hline
\end{tabular}




\begin{tabular}{|c|c|c|c|}
\hline Married & 0.085 & 0.154 & 0.055 \\
\hline & $(2.59)$ & $(3.82)$ & $(1.58)$ \\
\hline Proficient & -0.040 & -0.081 & 0.190 \\
\hline English & $(0.48)$ & $(0.87)$ & $(3.17)$ \\
\hline \multicolumn{4}{|c|}{ VisaCategory (Independent) } \\
\hline Refugee & 0.392 & 0.379 & -0.083 \\
\hline (Humanitarian) & $(2.58)$ & $(2.38)$ & $(0.78)$ \\
\hline Preferential & -0.090 & -0.124 & -0.250 \\
\hline Family & $(2.28)$ & $(2.55)$ & $(6.48)$ \\
\hline Concessional & -0.113 & -0.182 & -0.225 \\
\hline Family & $(2.27)$ & $(3.10)$ & $(4.75)$ \\
\hline Business & -0.003 & 0.021 & 0.018 \\
\hline Skills/ENS ${ }^{(a)}$ & $(0.04)$ & $(0.28)$ & $(0.22)$ \\
\hline Log Hours Worked & 1.051 & 0.527 & 0.786 \\
\hline per Week & $(24.22)$ & $(9.06)$ & $(16.11)$ \\
\hline Selectivity variable & -0.501 & -0.557 & -0.392 \\
\hline$(\lambda)$ & (3.37) & (3.97) & $(1.40)$ \\
\hline $\bar{R}^{2}$ & 0.507 & 0.370 & 0.457 \\
\hline
\end{tabular}




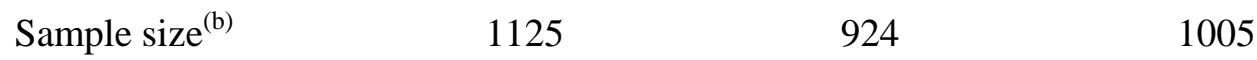

$\begin{array}{llll}\text { Mean Log Weekly } & 6.145 & 6.264 & 6.348\end{array}$

Earnings

For notes to Table, see Table 1.

Source: Longitudinal Survey of Immigrants to Australia (Waves One, Two and Three) 
Table 4: Regression Estimates of Logarithmic Weekly Earnings for Male Immigrants 15-64 Years of Age With a Job in Both Waves One and Three, Longitudinal Survey of Immigrants to Australia

\begin{tabular}{|c|c|c|c|c|}
\hline \multirow{4}{*}{ Variable } & \multicolumn{2}{|c|}{$\underline{\text { Cross-section Models }}$} & \multicolumn{2}{|c|}{ Inertia Model } \\
\hline & (i) & (ii) & (iii) & (iv) \\
\hline & Wave $1^{(a)}$ & Wave $3^{(\mathrm{b})}$ & Wave $3^{(\mathrm{b})}$ & Waves 1 and \\
\hline & & & & $3^{(\mathrm{c})}$ \\
\hline \multirow[t]{2}{*}{ Constant } & 1.921 & 3.179 & 1.263 & 1.259 \\
\hline & $(5.74)$ & (6.33) & $(2.95)$ & $(2.93)$ \\
\hline \multirow[t]{2}{*}{ Education (years)* } & 0.042 & 0.059 & 0.035 & 0.034 \\
\hline & $(6.00)$ & $(8.47)$ & $(5.60)$ & (5.68) \\
\hline Post-School Quals & 0.137 & 0.162 & 0.101 & 0.094 \\
\hline obtained in & $(1.78)$ & $(2.46)$ & $(2.17)$ & (1.99) \\
\hline \multicolumn{5}{|l|}{ Australia* } \\
\hline Pre-Immigration & 0.008 & 0.005 & 0.001 & 0.001 \\
\hline experience (years) & (2.89) & (1.79) & $(0.38)$ & $(0.38)$ \\
\hline Aust. labor market & 0.024 & 0.010 & 0.010 & 0.010 \\
\hline experience & $(2.33)$ & $(2.27)$ & $(2.59)$ & $(2.72)$ \\
\hline \multicolumn{5}{|l|}{ (months)* } \\
\hline English-speaking & 0.229 & 0.275 & 0.124 & 0.113 \\
\hline developed countries & $(4.11)$ & $(5.77)$ & $(3.52)$ & $(3.21)$ \\
\hline
\end{tabular}




\begin{tabular}{|c|c|c|c|c|}
\hline \multirow[t]{2}{*}{ Married* } & 0.039 & 0.024 & 0.008 & -0.009 \\
\hline & $(1.13)$ & $(0.62)$ & $(0.25)$ & $(0.32)$ \\
\hline Proficient in & 0.151 & 0.237 & 0.149 & 0.151 \\
\hline English* & (3.12) & $(2.60)$ & $(1.90)$ & $(2.88)$ \\
\hline \multicolumn{5}{|c|}{ Visa category (Independent) } \\
\hline \multirow[t]{2}{*}{ Refugee } & -0.164 & -0.334 & -0.130 & -0.101 \\
\hline & $(2.08)$ & $(2.64)$ & $(1.02)$ & $(0.74)$ \\
\hline \multirow[t]{2}{*}{ Preferential Family } & -0.101 & -0.213 & -0.138 & -0.129 \\
\hline & $(2.88)$ & $(6.01)$ & $(4.88)$ & $(4.43)$ \\
\hline Concessional & -0.155 & -0.251 & -0.156 & -0.152 \\
\hline Family & (3.12) & $(5.21)$ & (3.68) & $(3.70)$ \\
\hline Business & -0.086 & -0.038 & -0.123 & -0.121 \\
\hline Skills/ENS & $(1.09)$ & $(0.57)$ & $(2.24)$ & $(2.21)$ \\
\hline Log hours worked & 0.937 & 0.517 & 0.455 & 0.457 \\
\hline per week* & $(11.42)$ & $(4.03)$ & (3.93) & (3.99) \\
\hline Log earnings & (d) & (d) & 0.570 & -0.436 \\
\hline (wave 1) & & & (14.41) & (10.94) \\
\hline
\end{tabular}


Log hours worked

(d)

(d)

$-0.250$

$-0.238$

per week (wave 1)

$\bar{R}^{2}$

0.475

0.365

0.597

0.439

Sample size

665

665

665

665

Mean Log

6.188

6.447

6.447

0.258

weekly earnings

${ }^{(a)}$ Dependent variable is logarithmic earnings in wave 1.

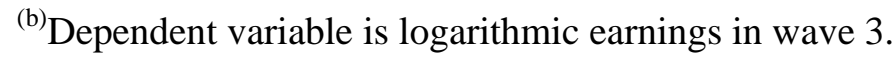

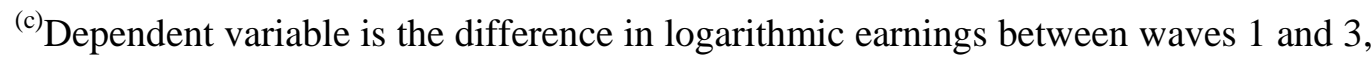
that is, wave 3 minus wave 1 .

${ }^{(d)}$ Not relevant.

* Variable varies across waves.

Source: Longitudinal Survey of Immigrants to Australia (Waves One, Two and Three) 
Table 5: Regression Estimates of Inertia Model using Predicted Lagged Wage Variable for Male Immigrants 15-64 Years of Age With a Job in Both Waves One and Three, Longitudinal Survey of Immigrants to Australia

\begin{tabular}{|c|c|c|}
\hline \multirow[b]{3}{*}{ Variable } & \multicolumn{2}{|c|}{$\underline{\text { Inertia Model }}$} \\
\hline & (i) & (ii) \\
\hline & Wave $3^{(b)}$ & Waves 1 and $3^{(\mathrm{c})}$ \\
\hline \multirow[t]{2}{*}{ Constant } & 0.889 & 2.314 \\
\hline & $(1.26)$ & $(2.26)$ \\
\hline \multirow[t]{2}{*}{ Education (years)* } & 0.027 & 0.056 \\
\hline & $(1.91)$ & $(2.92)$ \\
\hline Post-School Quals obtained in & 0.072 & 0.174 \\
\hline Australia* & $(1.20)$ & $(1.98)$ \\
\hline \multirow[t]{2}{*}{ Pre-Immigration experience (years) } & -0.001 & 0.005 \\
\hline & $(0.21)$ & $(1.18)$ \\
\hline Aust. Labor market & 0.009 & 0.013 \\
\hline experience (months)* & $(2.31)$ & $(2.49)$ \\
\hline English-speaking developed & 0.077 & 0.240 \\
\hline countries & $(1.03)$ & $(2.13)$ \\
\hline
\end{tabular}


Visa Category (Independent)

Refugee

Preferential Family

Concessional

Family

Business

Skills/ENS

Log hours worked per week*

Predicted Log earnings (wave 1)
$-0.086$

$-0.201$

(0.61)

$-0.114$

$-0.193$

(2.50)

$-0.124$

$-0.239$

(2.07)

$-0.149$

$-0.050$

(2.25)

(0.56)

0.456

0.300

(3.88)

(0.67)

0.773

$-1.001$

(2.72) 
Log hours worked per week (wave 1)

$-0.443$

0.454

(1.57)

Sample size

665

665

Mean Log

6.447

0.258

weekly earnings

For notes to table, see Table 4.

Source: Longitudinal Survey of Immigrants to Australia (Waves One, Two and Three) 


\section{Figure 1}

\section{Schematic Representation of Possible Job Histories}

\section{for Hypothetical Respondents}

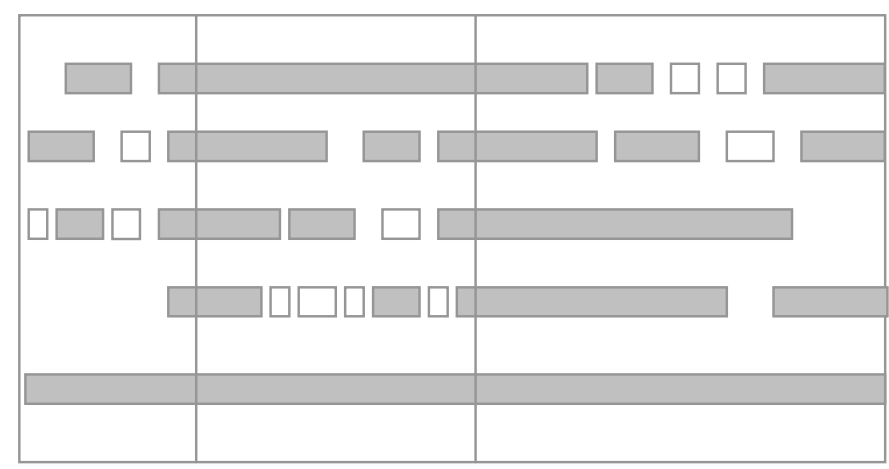

$\begin{array}{cccc}\text { Arrival in } & \text { Wave 1 } & \text { Wave 2 } & \text { Wave } 3 \\ \text { Australia } & \text { Interview } & \text { Interview } & \text { Interview }\end{array}$


Figure 2

\section{Standardised Logarithmic Earnings of 15-64 Year Old Male}

Immigrants With a Job at Time of Each Interview By Visa

\section{Categories,}

\section{Longitudinal Survey of Immigrants to Australia}

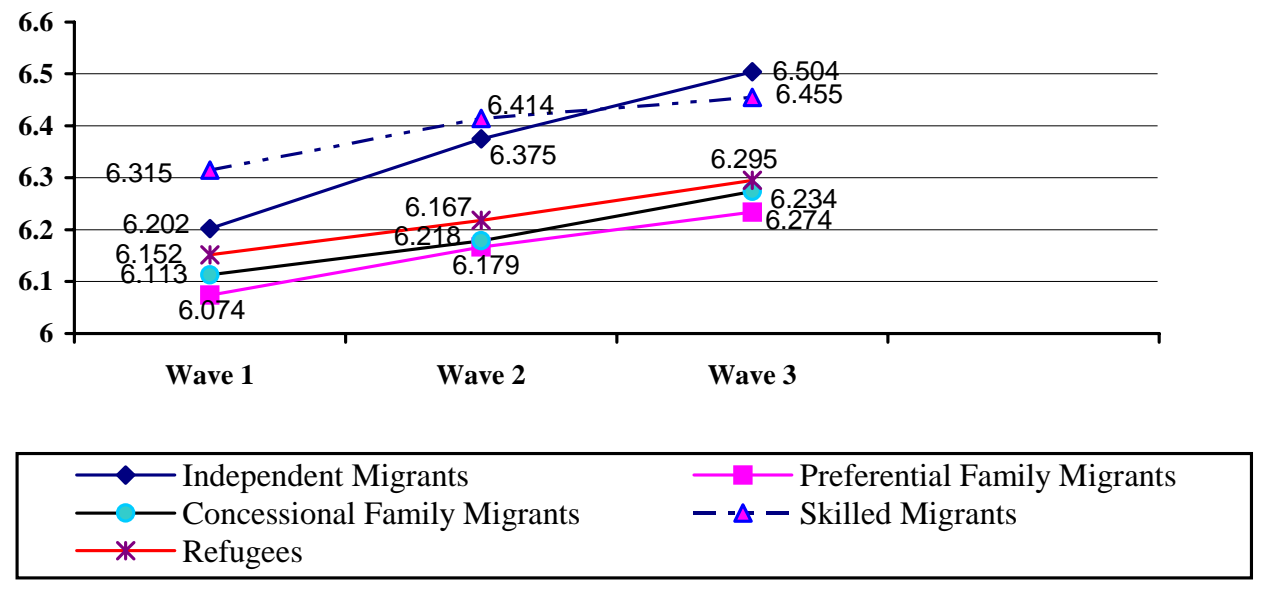




\section{REFERENCES}

Borjas, George, “Assimilation, Changes in Cohort Quality, and the Earnings of Immigrants,” Journal of Labor Economics, Vol. 3, No. 4, 463-489, 1985.

Chiswick, Barry R., “The Effect of Americanization on the Earnings of Foreign-Born Men,” Journal of Political Economy, Vol. 85, No. 5, October, 897-921, 1978.

"The Economic Progress of Immigrants: Some Apparently Universal

Patterns,” in William Fellner, ed., Contemporary Economic Problems 1979, American Enterprise Institute, Washington, 357-399, 1979.

“An Analysis of the Economic Progress and Impact of Immigrants,” National Technical Information Service PB 80-200454, Washington, D.C., 1980.

"Is the New Immigration Less Skilled than the Old?” Journal of Labor

Economics, Vol. 4, No. 1, April, 168-192, 1986.

“Are Immigrants Favorably Self-Selected?” American Economic

Review, Vol. 89, No. 2, May, 181-185, 1999.

Chiswick, Barry R., Lee, Yew L. and Miller, Paul W., "Longitudinal Analysis of Immigrant Occupational Mobility: A Test of the Immigrant Assimilation Hypothesis,” International Migration Review, 39 (2) Summer, 332-353, 2005. 
Chiswick, Barry, R. and Miller, Paul W., "Immigrant Generation and Earnings in Australia,” Economic Record, Vol. 61, No. 173, 540-553, 1985.

Dolton, Peter J. and Makepeace, Gerry H., “Interpreting Sample Selection Effects”, Economic Letters, Vol. 24, 373-379, 1987.

“Computer Use and Earnings in Britain,” Economic Journal, Vol. 114, C117-C129, 2004.

Duleep, Harriet Orcutt and Regets, Mark C., “The Elusive Concept of Immigrant Quality: Evidence from 1970-1990,” Discussion Paper PRIP-UI-41, Program for Research on Immigration Policy, Urban Institute, Washington, DC, 1996.

"Measuring Immigrant Wage Growth Using Matched CPS Files," Demography, Vol. 34, No. 2, 239-249, 1997.

Greene, William H., Econometric Analysis, MacMillan Publishing Company, New York, 1991.

Heckman, James J., “Sample Selection Bias as a Specification Error,” Econometrica, Vol. 47, No. 1, 153-161, 1979.

Le, Anh T. and Miller, Paul W., "The Persistence of the Female Wage Disadvantage,” Australian Economic Review, Vol. 34, No. 1, 33-52, 2001. 
Lillard, Lee A. and Willis, Robert J., "Dynamic Aspects of Earnings Mobility,” Econometrica, Vol. 46, 985-1012, 1978.

McManus, Walter, Gould, William and Welch, Finis, "Earnings of Hispanic Men: The Role of English Language Proficiency,” Journal of Labor Economics, Vol. 1, No. 2, April, 101-130, 1983.

Miller, Paul W., “Low-Wage Youth Employment: A Permanent or Transitory State,” Economic Record, Vol. 65, 126-135, 1989.

Miller, Paul and Volker, Paul, “The Youth Labor Market in Australia: A Survey of Issues and Evidence,” Centre for Economic Policy Research, The Australian National University, Discussion Paper No. 171, 1987.

Nakamura, Alice and Nakamura, Masao, “The Second Paycheck: A Socioeconomic Analysis of Earnings,” Academic Press, New York, 1985.

Turkington, Darrell A., “A Note on Two-Stage Least Squares, Three-Stage Least Squares and Maximum Likelihood Estimation in an Expectations Model,” International Economic Review, Vol. 26, No. 2, 507-510, 1985. 


\section{ENDNOTES}

${ }^{1}$ Administrative data sets for some countries, in particular the Scandinavian countries, can in principle provide longitudinal data on earnings, but they are generally weaker on other characteristics, such as country of origin, schooling, language proficiency and visa at entry.

${ }^{2}$ The Principal Applicant is the person upon whom the approval to immigrate was based. There is only one principal applicant per family. Excluded from the survey are New Zealand citizens, who do not require a visa to enter Australia, and those granted a visa while resident in Australia.

${ }^{3}$ The five main visa categories are Preferential Family (42.3 percent of the sample), Concessional Family (15.0 percent), Business Skills and Employer Nomination (10.2 percent), Independent (16.5 percent), and Humanitarian (16.0 percent). The Business Skills/Employer Nominated Scheme and Independent category immigrants are skills tested and are considered as economic immigrants in this analysis. The Concessional Family and Preferential Family Categories are based on kinship to Australians, although the Concessional Family Category includes more distant relatives and a “points test" based on skills and age. The Humanitarian Category is primarily refugees.

${ }^{4}$ The inclusion of an experience-squared variable produces very similar results to models without this variable for each wave. The coefficients of the experience- 
squared variables were statistically insignificant and were, therefore, omitted from the equations reported.

5 The Australian labor market experience variable could also capture effects associated with the length of time immigrants took to find their first job in Australia. See Chiswick, Lee and Miller (2005), where it was shown that there was a pronounced negative association between the length of time it took an immigrant to obtain his/her first job in Australia and the occupational status of that job. Replacing the Australian labor market experience variable with one that recorded the length of time taken to obtain the first job in Australia resulted in the latter variable being statistically significant. However, including both of these variables in an encompassing model indicated the labor market experience variable was superior.

${ }^{6}$ Obviously, the hours worked variable that is relevant only to the paid employment sample, and the Australian labor market experience variable, which is zero for many of those not in paid employment at the time of an interview, cannot be included in the reduced form selection equation.

${ }^{7}$ Dolton and Makepeace (2004) term this model a value added specification. They outline the restrictions inherent in the model. Comparison of the results from this approach with panel data estimators in Dolton and Makepeace (2004) suggests it may provide a reasonable way of capturing unobserved individual endowments.

\footnotetext{
${ }^{8}$ For a discussion of the properties of this two-step procedure, see Turkington (1985).
} 